\title{
Antimicrobial Resistance: Identifying the Major Conflicts of Interest and Way Forward
}

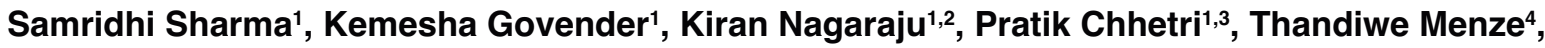 \\ Sunitha C Srinivas ${ }^{1^{*}}$
}

${ }^{1}$ Faculty of Pharmacy, Rhodes University, Grahamstown, SOUTH AFRICA

2Department of Pharmacy Practice, Visveswarapura Institute of Pharmaceutical Sciences, Bengaluru, Karnataka, INDIA

${ }^{3}$ LMIC Chapter Coordinator, Universities Allied for Essential Medicines (UAEM), California, USA

${ }^{4}$ Principle Faculty Librarian: Science and Pharmacy, Rhodes University, Grahamstown, SOUTH AFRICA.

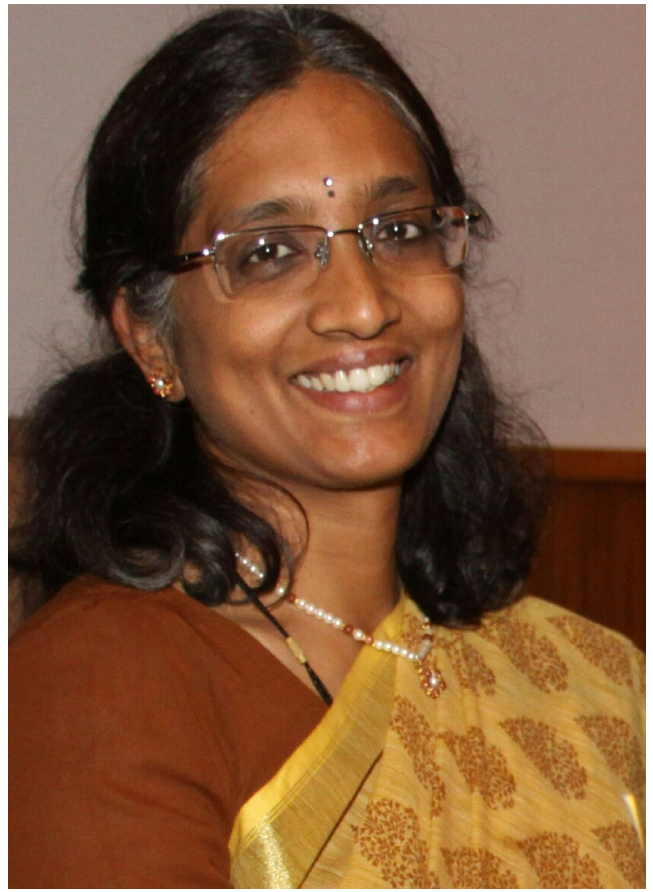

\section{INTRODUCTION}

"We find ourselves on the brink of a post-antibiotic era" - Department of Health Republic of South Africa, 2015. ${ }^{1}$ According to the World Health Organisation (WHO), antimicrobial resistance (AMR) is a global threat to public health. ${ }^{2}$ AMR causes around 700000 deaths every year, and is projected to lead to 10 million deaths annually by $2050 .{ }^{3,4}$ By $2050,4,73,0000$ deaths in Asia and 4,15,0000 deaths in Africa will be attributable to AMR. ${ }^{3}$ Over-prescription and irrational use of antimicrobials result in the development and spread of AMR, which is worsened by poor infection control in clinics and hospitals as well as by poor sanitation. ${ }^{2}$ AMR results in more infections, for longer durations; increased duration and frequency of hospital admissions; and increased health-related expenses. Inadequate knowledge is partly responsible for inappropriate prescription, which may further increase morbidity and mortality rates. ${ }^{5-7}$ Poverty contributes to the increase of AMR, as patients tend to share antimicrobials or use leftovers to treat infections. ${ }^{8}$ Patients require counselling and education on the correct use of antimicrobials and the importance of hygiene to prevent AMR and to maintain healthy living.? Wide spread use of antimicrobials in the agricultural industry also contributes significantly to the emergence and spread of antimicrobial resistance. Large quantities of antibiotics are used for growth promotion, as well as for prophylaxis and to treat infections in intensively farmed animals, to prevent economic losses. ${ }^{9} 10$ Therefore, due to a potential conflict of commercial interest, the risk of policies failing to tackle AMR is also high. ${ }^{11}$ While existing antimicrobials are becoming ineffective at a high rate, there is slow to minimal development of new antimicrobial agents. ${ }^{12}$

AMR has a major negative impact on some major diseases such as TB, pneumonia, malaria, and HIV, especially in developing nations such as South Africa and India. As antimicrobial agents become more ineffective, treatment of these diseases becomes more difficult. ${ }^{7,13,14}$ Anti-
DOI: 10.5530/ijopp.10.2.16

Address for correspondence: Sunitha C Srinivas, Faculty of Pharmacy, Rhodes University, Grahamstown, SOUTH AFRICA

E-mail: s.srinivas@ru.ac.za 
microbials do not possess a unilateral role of therapy. They are required for successful treatment of various communicable and non-communicable diseases (NCDs), ${ }^{2}$ further complicating the double burden of diseases in developing countries. ${ }^{15}$ Without effective antimicrobials, death due to infectious diseases will continue to rise, while NCD related issues such as chemotherapy and heart surgery would increasingly become high risk as prophylaxis antibiotics would be unavailable. ${ }^{16}$

Although AMR is a major threat to public health, aggressive and effective actions in developing countries are yet to begin. Below is a summary of events, in the form of a timeline, for HIV/AIDS, AMR, and NCDs, to depict the disparity of resolutions to decrease the threats posed by resistant microbes. As AMR influences infectious diseases such as HIV/ AIDS and NCDs, a few important milestones in these three are shown. Table 1 below shows some of the important milestones achieved as an outcome of global, regional, and national responses.

While antibiotics are considered one of the most significant discoveries of the $20^{\text {th }}$ century, the real challenge is the increased prevalence of AMR seen in hospitals, communities, as well as the environment in which antibiotics are used. ${ }^{29}$ Table 2 highlights some of the major milestones in AMR resolutions.

Progress in managing this major global public health problem is shown using an NCD related example. A clear conflict of interest emerges when considering economic generation and job creation among the food, beverage, and cigarette industries, and demonstrates how UN and governments have to manage the conflict of revenue generation of these major industries against the NCD pandemics they cause, especially in developing countries. Table 3 below

Table 1: Timeline for HIV/AIDS Resolutions.

Timeline

2030

2020

2017

2016

2015

2010

2008

2004

2002

2001

2000

1987

1985

1980 s

\section{HIVIAIDS}

Target year for ending AIDS epidemic ${ }^{17}$

The UNAIDS "90-90-90" targets for 2020 - 90\% of HIV positive population to know their HIV status, $90 \%$ of patients diagnosed with HIV to receive antiretroviral therapy, and $90 \%$ of those on antiretroviral therapy to achieve viral suppression ${ }^{17}$

In July, WHO will launch the first Global Action Plan on HIV Drug Resistance ${ }^{17}$

WHO launched its "treat all" consolidated guidelines on the strategic use of antiretroviral therapy for both treatment and prevention $^{17}$

WHO prequalified over 250 pharmaceutical products for treating HIV-related conditions, 29 active pharmaceutical ingredients (APIs), and two devices for male circumcision ${ }^{17}$

MDG 6's target of 15 million people on HIV treatment by 2015 was met nine months ahead of schedule. ${ }^{18,19}$

Declaration of Sustainable Development Goals (SDGs); SDG 3 targeting to fully eradicate AIDS epidemic by $2030^{18,20}$

UNITAID established the Medicine Patent Pool (MPP) to increase access to HIV, viral hepatitis C and TB treatments in lowand middle-income countries (LMICs) ${ }^{21}$

WHO introduced a new treatment framework of a five-pronged programmatic approach, to increase accessibility, safety, effectiveness and efficiency of antiretroviral therapy ${ }^{17}$

At the 17th International AIDS Conference in Mexico City, WHO launched a set of priority interventions to assistLMICsachieve universal access to HIV prevention, treatment, care, and support ${ }^{17}$

004 The Oral Health and Disease in AIDS Conference in Phuket, Thailand issued the Phuket Declaration toencourage research and strengthen oral health promotion and the care of HIV-infected persons ${ }^{22}$

- Global Fund to Fight AIDS, TB and Malaria found ${ }^{18}$

Heads of State and Representatives of Governments issued Declaration of Commitment on HIVIAIDS at the United Nations General Assembly Special Session (UNGASS) ${ }^{23}$

The Doha Declaration by World Trade Organisation, allowing developing countries to buy or manufacture generic medicines for public health crises such as HIVIAIDS ${ }^{18}$

The South African law allowed the government to purchase any brand-namedAIDS medicines at the lowest rates, provided the medicines compliedwith international trade agreements ${ }^{24}$

WHO prequalification established as a response to the HIVIAIDS pandemic to guide UN and others to procure quality $\mathrm{ARV}^{25}$

U.S National Security Council and UN Security Council both declared HIVIAIDS a security threat ${ }^{18,26}$

Declaration of 8 Millennium Development Goals (MDGs); MDG 6 was to combat HIVIAIDS, malaria and other diseases ${ }^{18,27}$

First antiretroviral (ARV) medicine, zidovudine, approved by U.S. FDA ${ }^{18,26}$

WHO launched Global Programme on AIDS 18,26

First International AIDS Conference which took place in Atlanta ${ }^{26}$

People first became aware of HIVIAIDS ${ }^{28}$ 
Table 2: Timeline for AMR Resolutions.

\begin{tabular}{|c|c|}
\hline AMR & AMR resolutions \\
\hline 2017 & $\begin{array}{l}\text { The World Health Assembly resolution } 68.7 \text { requested for all national action plans to be completed by May. }{ }^{30} \\
\text { WHO issued a list of the } 12 \text { most important antibiotic-resistant bacteria, in addition to Mycobacterium tuberculosis, requiring } \\
\text { urgent R\&D. }{ }^{31,32}\end{array}$ \\
\hline 2016 & $\begin{array}{l}\text { The Combating Antibiotic Resistant Bacteria Biopharmaceutical Accelerator (CARB-X) established an international partnership } \\
\text { to tackle antimicrobial resistance. }{ }^{33} \\
\text { Davos Declaration at World Economic Forum by Pharmaceutical, Biotechnology and Diagnostics Industries on combating } \\
\text { antimicrobial resistance. }{ }^{34} \\
\text { Leading pharmaceutical companies presented industry roadmap with key commitments to be delivered by } 2020 \text { to reduce } \\
\text { antimicrobial resistance. }{ }^{34} \\
\text { United Nations General Assembly held the first high-level meeting on antimicrobial resistance and passed a political } \\
\text { declaration. } \\
\text { The Drugs for Neglected Diseases initiative along with WHO launched a global research and development partnership to } \\
\text { develop and promote the rational use of new antibiotics. }{ }^{30}\end{array}$ \\
\hline 2015 & Governments at the World Health Assembly adopted a global action plan to tackle antimicrobial resistance..$^{30}$ \\
\hline 2014 & $\begin{array}{l}\text { The } 67 \text { th World Health Assembly resolution WHA } 67.25 \text { called for the development of the global action plan on antimicrobial } \\
\text { resistance. }{ }^{37}\end{array}$ \\
\hline 2011 & $\begin{array}{l}\text { APUA, WHO, Rajasthan Society for Promotion of Rational Use of Drugs (RSPRUD), and International Society for Pharmaco- } \\
\text { economics and Outcomes Research (ISPOR) offered an "International Training Course on Promoting Rational Use of Drugs in } \\
\text { the Community" at the Institute of Health Management Research in Jaipur, India. }{ }^{38}\end{array}$ \\
\hline 2009 & Launch of WHO ‘SAVE LIVES: Clean Your Hands’ campaign. ${ }^{39}$ \\
\hline 2006 & Establishment of APUA South Africa. ${ }^{40}$ \\
\hline 1996 & Establishment of APUA India. ${ }^{38}$ \\
\hline 1981 & $\begin{array}{l}\text { Dr Stuart B. Levy founded Alliance for the Prudent Use of Antibiotics (APUA) as a global non-profit organisation, aiming to } \\
\text { improve antimicrobial use and contain antibiotic resistance. }{ }^{41}\end{array}$ \\
\hline 1977 & Emergence of multidrug resistance was first reported in Soweto, South Africa. ${ }^{42}$ \\
\hline 1960 & Appearance of antibiotic resistance in most developed countries. ${ }^{29,43}$ \\
\hline 1928 & Discovery of penicillin by Sir Alexander Fleming. ${ }^{16}$ \\
\hline
\end{tabular}

highlights some of the major milestones in NCD resolutions.

\section{Impact on South Africa and India}

South Africa is a unique country which suffers from a quadruple burden of disease. AMR has a mass effect on the people of this country, as $70,00,000$ in South Africa are living with HIV, and $43 \%$ of the country's total deaths are attributed to NCDs. ${ }^{46,47}$ Furthermore, the country's growth rate of $0.2 \%$ does not provide for forays towards more expensive medications. ${ }^{48}$ In India, 21,00,000 people are living with $\mathrm{HIV},{ }^{49}$ and $60 \%$ of total deaths are due to NCDs. ${ }^{50}$

The issue of AMR comes into play when the infrastructure and support system of the health care system is weak. Figures 1 and 2 below illustrate the healthcare personnel per 1,000 population in South Africa and India, respectively.

Health care providers fall short in prevention and control of AMR, along with other diseases. Along with insufficient staff compliments, the budget allocated to the healthcare sector poses further problems. South Africa and India spend 8.8\% and 4.7\% of their GDP on healthcare, respectively, which is much less than the $15 \%$ annual budget agreed by the Abuja Declaration. ${ }^{5456}$ Unsustainability is introduced when there is disproportionate sharing of the funds. In South Africa, less than $50 \%$ of the total GDP allocated to health expenditure is provided to the public sector, ${ }^{55,56}$ which caters for $84 \%$ of the country's population. ${ }^{57}$ AMR is a burden which could be prevented with sufficient health promotion and pharmaceutical care.

These are challenges and shortcomings in South Africa and India, as well as in other LMICs. The UN has put forward the Global Goals to end poverty, protect the planet, and ensure that all people enjoy peace and prosperity. ${ }^{58}$ There is also a relationship between health beliefs and the increased demand for antimicrobial medicines. Use of antimicrobial medicines is strongly influenced by social constraints and cultural views of infectious diseases requiring antimicrobial treatment. Therefore, several countries have launched national campaigns to educate physicians and patients about irrational use of antimicrobials and the risk of AMR. ${ }^{59}$ 
Table 3: Timeline for NCDs Resolutions.

\begin{tabular}{|c|c|}
\hline Timeline & NCDs resolutions \\
\hline 2025 & - To achieve the WHO Global NCD Action Plan. ${ }^{44}$ \\
\hline 2016 & $\begin{array}{c}\text { - The United Nations Economic and Social Council (ECOSOC) encouraged Task Force members to support nations in } \\
\text { bringing upon the new NCD-related targets mentioned in the } 2030 \text { Agenda for Sustainable Development into their national } \\
\text { responses. }{ }^{45} \\
\text { - The Global Hearts Initiative was launched by WHO, the US Centres for Disease Control and Prevention, and other } \\
\text { partners to reduce salt intake. }{ }^{45} \\
\text {-WHO issued its first Global report on diabetes. }{ }^{45}\end{array}$ \\
\hline 2015 & $\begin{array}{l}\text { - The WHO Model List of Essential Medicines included } 16 \text { low- and high-cost medicines which couldeither increase survival } \\
\text { periods for common cancers or successfully cure up to } 90 \% \text { of patients with rare cancers. } .^{45} \\
\text { - WHO issued new guidelines, which recommend limiting daily intake of free sugars to below } 10 \% \text { of total energy intake. } .^{45}\end{array}$ \\
\hline 2014 & $\begin{array}{l}\text { - The Global Coordination Mechanism to prevent and control NCDs established by the WHO Member States. }{ }^{45} \\
\text { - The WHO Commission on Ending Childhood Obesity established by the WHO Director-General. }{ }^{45}\end{array}$ \\
\hline 2013 & $\begin{array}{l}\text { - The World Health Assembly adopted a comprehensive global monitoring framework for NCDs. }{ }^{45} \\
\text {-WHO issued a Global brief on hypertension, and made blood pressure monitoring the theme for World Health Day to } \\
\text { increase public awareness. }{ }^{45}\end{array}$ \\
\hline 2011 & - The UN General Assembly held a high-level meeting on NCDs and adopted a far-reaching Political Declaration. ${ }^{45}$ \\
\hline 2010 & $\begin{array}{r}\text { - A set of recommendations on the marketing of foods and beverages containing high sugar, salt, and fats to children was } \\
\text { approved by the World Health Assembly. }{ }^{45} \\
\qquad \text { WHO issued its first Global recommendations on physical activity for health purposes. }{ }^{45}\end{array}$ \\
\hline 2007 & $\begin{array}{c}\text {-WHO issued a comprehensive approach towards surveillance, prevention and control of chronic respiratory diseases at } \\
\text { a global level. }{ }^{45}\end{array}$ \\
\hline
\end{tabular}

\section{Healthcare Personnel per 1,000 South African Population}

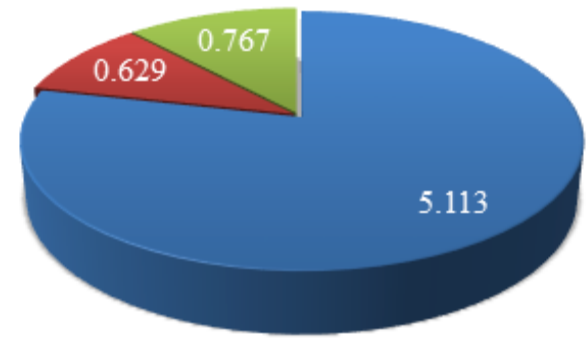

$\square$ Nurses and midwifery $\square$ Pharmaceutical $\square$ Physicians

Figure 1: Pie Chart for Healthcare Personnel per 1,000 South African Population. ${ }^{51-53}$

\section{Why the Slow Movement for AMR?}

AMR is a major global problem, yet relatively few actions have been taken to combat it. ${ }^{2}$ A comparison between Tables 1, 2 and 3 highlights the challenges with regards to correcting the potential crisis. It took decades before HIV/AIDS was given the attention it needed, and, ever since, the momentum to reduce its prevalence has been ongoing. Since HIV/ AIDS has a negative impact on public health and the economy, stringent policies were implemented. ${ }^{60,61}$ As compared to NCDs and AMR, HIV/AIDS did not face similar challenges with regards to self-serving and conflicts of interest of industries, other than the pharmaceutical industry. NCDs are the leading cause of death globally, although this too was an area which took time before major players like the

\section{Healthcare Personnel per 1,000 Indian Population}

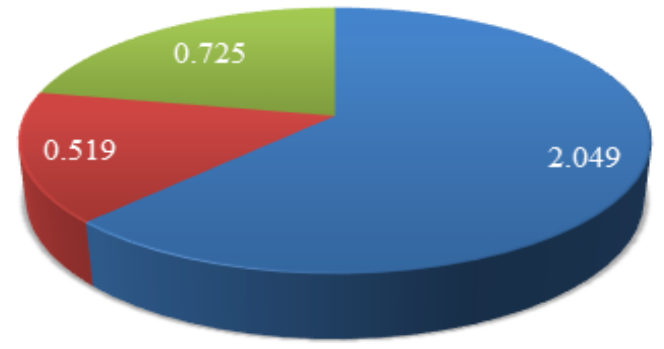

$\square$ Nurses and midwifery $\square$ Pharmaceutical $\square$ Physicians

Figure 2: Pie Chart for Healthcare Personnel per 1,000 Indian Population..$^{51-53}$

United Nations (UN) pushed for resolutions. ${ }^{62}$ Management and prevention of NCDs are challenging, as the significance of policy implementation is strongly influenced by the commercial interests of tobacco, alcohol, beverage, and processed food industries. These industries play an active role in influencing the public through advertisements, and policy-makers minimise regulation in order to maximise profits. ${ }^{63,64}$ Antimicrobials indirectly affect the mortality rates of both HIV/AIDS and NCDs. Therefore, $\mathrm{AMR}$ requires a greater force towards prevention as well as Research and Development (R\&D) of new antimicrobials.

According to pharmaceutical manufacturers, the lack of development of new antimicrobials is owed to the law of supply and demand. Since NCDs are 
the current focus of health concerns, the demand for treating these diseases is resulting in sufficient profits for manufacturers. ${ }^{12}$ The pharmaceutical industry is a key stakeholder in manufacturing and distributing antimicrobials, as well as in research and development $(\mathrm{R} \& \mathrm{D})$ of new antimicrobials. However, there is potential conflict of interest where profits are prioritized over patients' welfare, which acts as a limiting factor in combatting antimicrobial resistance..$^{65,66}$ AMR effects everyone around the world; therefore, there is a demand for new antimicrobials, particularly in LMICs. However, LMICs cannot afford to fund expensive $R \& D$ projects themselves, nor can they afford the expected high prices of these new antimicrobials.

If one considers the trend, and particularly the goal of stakeholders, it would become clear that action was taken against HIV/AIDS and NCDs only when the diseases progressed to and severely impacted high-income countries (HICs). As HICs can afford quality therapy, pharmaceutical industries are willing to develop and manufacture new treatment to meet the demand. According to the Access to Medicine Index, the top five pharmaceutical industries in providing access to medication for the year 2016 are Glaxo Smith Kline plc., Johnson \& Johnson, Novartis AG, Merck Kgaa and Merck \& Co Inc*. All five of these pharmaceutical industries mainly manufacture pharmaceutical products for NCDs and communicable diseases such as HIV/AIDS, which further indicates disease prevalence and increased demand. ${ }^{67-71}$

The Access to Medicines Index stimulates and guides pharmaceutical industries to cater more for populations in LMICs, which do not have access to essential medicines or vaccines. The Index analyses how the top 20 research-based pharmaceutical corporations make medicines, vaccines and diagnostics more accessible in LMICs. ${ }^{72}$ Excellent changes are being driven and integrated worldwide due to the rigorous analysis of best practices by multi-nationals ${ }^{73}$ with the production of 20 company report cards on six sections. ${ }^{74}$ Engaging with the pharmaceutical industry in strategic collaborations has resulted in the development of 420 products to respond to 51 of the most burdensome diseases identified in LMICs by the top 20 multinationals. ${ }^{75}$ To make products available and affordable, some pharmaceutical industries are demonstrating good practice in approaches towards needs-responsive product registration, and are also considering affordability to a greater extent. However, only $25 \%$ of the countries with high-need have product registration, and only $5 \%$ of pharma- ceuticals are covered by pricing strategies that meet the Index's criteria. And though there is increased licensing, large middle-income countries such as Mexico and Thailand, home to the majority of the world's poor, are excluded. ${ }^{76}$

Despite ongoing policies and support provided by the WHO since late 1970s with regards to essential medicines, one third of the global population (close to two billion people) to date do not have access to essential medicines. This aspect is now being propelled by the 'Towards Access 2030' supported by the Sustainable Development Goals. ${ }^{77}$

\section{Do the Sustainable Development Goals Help?}

The 8 Millennium Development Goals (MDGs) focused on health to a large extent, as MDG 4 reduce child mortality; MDG 5 - improve maternal health; and MDG 6 - combat HIV/AIDS, malaria and other diseases, were solely aimed at healthrelated issues. Furthermore, MDG 1 - eradicate extreme poverty and hunger, and MDG 6 both indirectly favoured the battle against AMR. ${ }^{78}$ Poverty is a huge risk factor to AMR, and influences responses to HIV/AIDS. It would involve the control of opportunistic diseases, which require the use of antimicrobials. The use of antimicrobials to control the opportunistic diseases would mean promoting the correct use of medication, so that mortality resulting from HIV is low. It may have also probed the development of new antimicrobials. MDGs have now passed, therefore we need to scrutinize the new way forward, as embodied in the Sustainable Development Goals (SDGs).

The SDGs comprise of 17 goals and 169 targets, ${ }^{79}$ but the focus is more generic than the MDGs. SDGs hold one goal dedicated to health; SDG 3 - good health and well-being. ${ }^{58}$ If equal efforts are being put into various types of diseases, then this may result in unsustainability and higher mortality rates, because the number of deaths in the world is owed to various diseases, but in different capacities. If SDG 3 and SDG 10 - reduced inequality - were yolked together, justice for health will be served. SDG 10 aims to create preferential treatment in trade for developing nations and least developed nations, which can help reduce inequalities by creating more export opportunities. ${ }^{80}$ If this is made possible, then LMICs would be able to import medications at more affordable rates, and increase the access to medicines, consequently reducing mortality rates and increasing sustainability. Since the effect of AMR is more pronounced in LMICs, and affordability is an abundant issue, this may create opportunity to address 
the problem. Furthermore, SDG 4 - quality education - when combined with SDG 3 and SDG 10, can create an even larger difference. Quality education at an early stage allows for children to develop basic cognitive and language skills, as well as EQ. ${ }^{81}$ SDG 4 also strongly supports the reduction of persistent disparities, which further supports SDG 10, and will indirectly aid in achieving SDG 3 , as health education may result in better self-care and self-management, and thus improve health outcomes. ${ }^{81,82}$

\section{WHO's Role in Combatting AMR}

Dr Marc Sprenger, WHO Director of the Antimicrobial Resistance Secretariat, states that many lowincome countries require greater support in tackling antimicrobial resistance. Over $90 \%$ of the global population resides in countries that have developed, or are currently developing, a national action plan on antimicrobial resistance. More than $80 \%$ of high-income countries have a national action plan in place, or are developing one. They are thus in a better position to tackle the challenges of antimicrobial resistance. In comparison, only about 30\% of low-income countries either have or are developing a national action plan. Low-income countries require greater support, as they lack expertise to develop a national action plan, and face greater exposure to infectious diseases, as their health systems are much weaker and lack preparedness. The newly elected WHO Director-General, Dr. Tedros Adhanom Ghebreyesus, also considers AMR one of the most complex global challenges faced by his leadership. ${ }^{83}$

In September 2016, global leaders met at the United Nations General Assembly to tackle the threat of AMR. This was the fourth time in history that a health-related problem was discussed in the meeting, which indicates the worldwide significance of AMR. A resolution was drafted which called for action, ensuring the appropriate use of antimicrobials across human as well as animal health. ${ }^{35,36}$

To tackle the challenges of antimicrobial resistance, the WHO, Food and Agriculture Organisation of the United Nations (FAO), and World Organisation for Animal Health (OIE) launched the Global Database for Antimicrobial Resistance Country Self-Assessment. This database presents information from a questionnaire which was distributed to nations in November 2016, and provides open access to nations' statutes regarding their action towards implementation of the global action plan on antimicrobial resistance. ${ }^{84}$
In 1977, the World Health Assembly of "Health for All" was used as a guiding principle, along with health policies to launch the WHO Model list of essential medicines. The WHO Essential Medicines List (EML), which is updated and revised biennially, is used by many nations as a measure to increase access to and availability of medicines. Many nations also use the EML as a guide to develop their own lists. The WHO Model list of essential medicines for 2017 includes information on which antibiotics to use for common infections, as well as which to use for more serious conditions. WHO experts grouped antibiotics into three categories - Access, Watch, and Reserve - and recommended when each category of antibiotics should be used, as shown in Table 1. This is to ensure availability of the required antibiotics and the appropriate prescription of antibiotics for a specific infection, further enhancing treatment outcomes and reducing the development of antimicrobial resistance. ${ }^{85}$

In 2017, the WHO also published the fifth revision of the Critically Important Antimicrobials for Human Medicines (CIA list). This CIA list is intended for all stakeholders involved in managing antimicrobial resistance, and ensures that all antimicrobials are used appropriately in human and veterinary medicine. ${ }^{87}$ On 27 February 2017, upon requests by Member States, WHO published a priority pathogens list of antibiotic-resistant bacteria. The list is a catalogue containing 12 families of bacteria that pose the highest threat to public health, and promotes research and development (R\&D) of new and effective antibiotics. ${ }^{88}$ Table 2 below shows the WHO priority pathogens list, along with their priority status and the antibiotics to which the pathogen is resistant.

The grave concerns AMR carries is the reason the WHO recently announced formation of an ad hoc Interagency Coordination Group (IACG) in March 2017, co-chaired by the UN Deputy Secretary-General and the WHO Director-General. Using expertise from appropriate stakeholders, the IACG guides required approaches to ensure sustained effective global actions to tackle and combat AMR. ${ }^{89} \mathrm{WHO}$ continues to encourage individuals to engage in hand hygiene and infection prevention and control programmes by participating in the 'SAVE LIVES: Clean Your Hands' campaign, which is held annually on or around 5 May. For the 2017 campaign, the materials were co-branded with 'Antibiotics, handle with care' as hand hygiene is key for effective infection prevention and control to combat antimicrobial resistance. ${ }^{90}$ Furthermore, the World Antibiotic Awareness Week, which will be held from 
13 to 19 November 2017, aims to raise awareness of antimicrobial resistance and to encourage optimum practices amongst the public, health workers, farmers, food-producing companies, veterinarians, and policy makers, in order to avoid antimicrobial resistance from developing further. ${ }^{87}$

\section{Youth Empowerment}

Youth and young health care professionals have been excellent examples in bringing about change and driving progressive solutions. Innovation, access, and empowerment have become the three pillars for Universities Allied for Essential Medicines, ${ }^{91}$ responsible for several positive changes in the area of access to essential medicines ${ }^{92-94}$ including antibiotics. ${ }^{95}$ Young professionals are driving this process, while gathering evidence and increasing their outreach in the form of publications ${ }^{96-99}$ as well, to coordinate focussed activities on essential medicines. While literature surrounding adult leadership focusses on "issues of authority (voice, influence, and decisionmaking power)", youth leadership tends to focus on "issues of ability (skills, knowledge, and talents)". ${ }^{100}$ Youth leadership positively influences community participation as knowledge of policies is put into action for the well-being of society. ${ }^{101}$

\section{CONCLUSION}

Education on the rational use of antimicrobials is key for agricultural industries, healthcare professionals, and patients. AMR awareness is essential for the public, as health education positively affects individuals' health and well-being. Youth participation demonstrates a positive effect on outcomes, including its effect on community change. ${ }^{101}$

As advocated by $\mathrm{WHO}$, policies at a national and international level are needed to tackle AMR. Coordinated initiatives are needed to convince the public and policy- and decision-makers of the medical as well as economic advantages of combatting AMR. ${ }^{9}$ There is also an urgent need for R\&D addressing newly prioritised antibiotic resistant-pathogens. ${ }^{32}$

\section{REFERENCES}

1. Department of Health Republic of South Africa. Implementation Plan for the Antimicrobial Resistance Strategy Framework in South Africa: 2014-2019 [Internet]. 2015 [cited 2017 Jun 26]. Available from: http://www.health.gov.za/ index.php/antimicrobial-resistance?download=1175:implementation-plan-forthe-antimicrobial-resistance-strategy-framework-in-south-africa-2014-2019.

2. WHO. Antimicrobial resistance [Internet]. who.int. 2016 [cited 2017 Jun 20]. Available from: http://www.who.int/mediacentre/factsheets/fs194/en/.

3. Review on Antimicrobial Resistance. Antimicrobial Resistance: Tackling a crisis for the health and wealth of nations [Internet]. 2014 [cited 2017 Jun 20].
4. Robinson TP, Bu DP, Carrique-Mas J, Fèvre EM, Gilbert M, Grace D, et al. Antibiotic resistance is the quintessential One Health issue. Trans $R$ Soc Trop Med Hyg. 20161;110(7):377-80.

5. Smith RD, Coast J. Antimicrobial resistance: a global response. Bull World Health Organ. 2002;80(2):126-33.

6. WHO. 10 Facts on Antimicrobial Resistance [Internet]. who.int. [cited 2017 Jun 20]. Available from: http://www.who.int/features/factfiles/antimicrobial_ resistance/facts/en/index9.html.

7. WHO. Antibiotic resistance [Internet]. who.int. 2016 [cited 2017 Jun 20]. Available from: http://www.who.int/mediacentre/factsheets/antibioticresistance/en/.

8. Planta MB. The role of poverty in antimicrobial resistance. J Am Board Fam Med JABFM. 2007;20(6):533-9.

9. Roca I, Akova M, Baquero F, Carlet J, Cavaleri M, Coenen S, et al. The global threat of antimicrobial resistance: science for intervention. New Microbes New Infect. 2015;16(6):22-9.

10. Chang Q, Wang W, Regev-Yochay G, Lipsitch M, Hanage WP. Antibiotics in agriculture and the risk to human health: how worried should we be? Evol Appl. 2015;8(3):240-7.

11. Lhermie G, Gröhn YT, Raboisson D. Addressing Antimicrobial Resistance: An Overview of Priority Actions to Prevent Suboptimal Antimicrobial Use in FoodAnimal Production. Front Microbiol [Internet]. 2017 Jan 6;7. Available from: http://www.ncbi.nlm.nih.gov/pmc/articles/PMC5216048/.

12. Powers JH. Antimicrobial drug development - the past, the present, and the future. Clin Microbiol Infect. 2004;10(S4):23-31.

13. Mendelson M, Matsoso MP. The South African Antimicrobial Resistance Strategy Framework [Internet]. 2015 [cited 2017 Jun 20]. Available from: http:// www.fidssa.co.za/Content/Documents/2015_01.pdf.

14. South African Department of Health. Antimicrobial Resistance Background Document [Internet]. [cited 2017 Jun 20]. Available from: http://www.fidssa. co.za/Content/Documents/AMR_Background_document_FINAL_March15.pdf.

15. Gutiérrez-Delgado C, Guajardo-Barrón V. The double burden of disease in developing countries: the Mexican experience. Adv Health Econ Health Serv Res. 2009;21:3-22.

16. Ventola CL. The Antibiotic Resistance Crisis. Pharm Ther. 2015;40(4):277-83.

17. WHO. HIV: from a devastating epidemic to a manageable chronic disease [Internet]. who.int. 2017 [cited 2017 Jun 21]. Available from: http://www.who.int/ publications/10-year-review/hiv/en/.

18. The Henry J. Kaiser Family Foundation. Global HIVIAIDS Timeline [Internet]. kff.org. 2016 [cited 2017 Jun 25]. Available from: http://www.kff.org/globalhealth-policy/timeline/global-hivaids-timeline/.

19. UNAIDS. UNAIDS announces that the goal of 15 million people on life-saving HIV treatment by 2015 has been met nine months ahead of schedule. 2015 Jul 14 [cited 2017 Jun 25]; Available from: http://www.unaids.org/en/resources/ presscentre/pressreleaseandstatementarchive/2015/july/20150714_PR_ MDG6report.

20. United Nations. Sustainable Development Goals - Goal 3 [Internet]. un.org. 2017 [cited 2017 Jun 25]. Available from: http://www.un.org/sustainabledevelopment/ health/.

21. MPP. About the Medicines Patent Pool (MPP) [Internet]. medicinespatentpool. org. [cited 2017 Jun 25]. Available from: http://www.medicinespatentpool.org/ about/.

22. Petersen P-E. Policy for prevention of oral manifestations in HIVIAIDS: the approach of the WHO Global Oral Health Program. Adv Dent Res. 2006 Apr $1 ; 19(1): 17-20$.

23. UNAIDS. Keeping the Promise - Summary of the Declaration of Commitment on HIVIAIDS [Internet]. 2002 [cited 2017 Jun 21]. Available from: http://www. unaids.org/sites/default/files/sub_landing/files/jc668-keepingpromise_en.pdf.

24. Swarns RL. Drug Makers Drop South Africa Suit Over AIDS Medicine. The New York Times [Internet]. 2001 Apr 20 [cited 2017 Jun 21]; Available from: https:// www.nytimes.com/2001/04/20/world/drug-makers-drop-south-africa-suit-overaids-medicine.html.

25. WHO. Essential Medicines and Health Products: Prequalification of Medicines Programme [Internet]. extranet.who.int. 2017 [cited 2017 Jun 25]. Available from: https://extranet.who.int/prequal/content/overview-history-mission.

26. CDC. CDC Global HIVIAIDS Milestones: On the Path to an AIDS-Free Generation [Internet]. cdc.gov. [cited 2017 Jun 25]. Available from: https://www. cdc.gov/globalaids/global-hiv-aids-at-cdc/aids-free-generation.html.

27. Millennium Project. About the MDGs [Internet]. unmillenniumproject.org. 2006 [cited 2017 Jun 25]. Available from: http://www.unmillenniumproject.org/goals/. 
28. AVERT. Origin of HIV \& AIDS [Internet]. avert.org. 2017 [cited 2017 Jun 21]. Available from: https://www.avert.org/professionals/history-hiv-aids/origin.

29. Davies J, Davies D. Origins and Evolution of Antibiotic Resistance. Microbiol Mol Biol Rev. 2010;74(3):417-33.

30. Inoue H, Minghui R. Antimicrobial resistance: translating political commitment into national action. Bull World Health Organ. 2017;95(4):241-312.

31. WHO. WHO publishes list of bacteria for which new antibiotics are urgently needed [Internet]. who.int. 2017 [cited 2017 Jun 26]. Available from: http://www. who.int/mediacentre/news/releases/2017/bacteria-antibiotics-needed/en/.

32. WHO. WHO stresses urgent need for R\&D for drug-resistant TB alongside newly-prioritized antibiotic-resistant pathogens [Internet]. who.int. 2017 [cited 2017 Jun 25]. Available from: http://www.who.int/mediacentre/news/ releases/2017/drug-resistant-tb/en/.

33. California Life Sciences Institute. International Partnership Established To Tackle Antimicrobial Resistance. 2016 Jul 28 [cited 2017 Jun 25]; Available from: http://califesciencesinstitute.org/international-partnership-established-totackle-antimicrobial-resistance/.

34. IFPMA. Leading Pharmaceutical Companies Present Industry Roadmap to Combat Antimicrobial Resistance [Internet]. 2016 [cited 2017 Jun 25]. Available from: https://www.ifpma.org/wp-content/uploads/2016/09/AMR-RoadmapPress-Release_FINAL.pdf.

35. Thursky K. Milestones, challenges in antimicrobial stewardship [Internet]. doctorportal.com.au. 2017 [cited 2017 Jun 25]. Available from: https://www. doctorportal.com.au/mjainsight/2017/2/milestones-challenges-in-antimicrobialstewardship/.

36. WHO. United Nations high-level meeting on antimicrobial resistance [Internet]. who.int. 2016 [cited 2017 Jun 25]. Available from: http://www.who.int/ mediacentre/events/2016/antimicrobial-resistance/en/.

37. WHO. Global Action Plan on Antimicrobial Resistance [Internet]. 2015 [cited 2017 Jun 25]. Available from: http://www.wpro.who.int/entity/drug_resistance/ resources/global_action_plan_eng.pdf.

38. APUA. India - Alliance for the Prudent Use of Antibiotics [Internet]. apua.org. 2016 [cited 2017 Jun 25]. Available from: http://apua.org/india/.

39. WHO. About SAVE LIVES: Clean Your Hands [Internet]. who.int. 2017 [cited 2017 Jun 25]. Available from: http://www.who.int/gpsc/5may/background/en/.

40. APUA. South Africa - Alliance for the Prudent Use of Antibiotics [Internet]. apua. org. 2016 [cited 2017 Jun 25]. Available from: http://apua.org/south-africa/.

41. APUA. Our History - Alliance for the Prudent Use of Antibiotics [Internet]. apua. org. 2016 [cited 2017 Jun 25]. Available from: http://apua.org/ourhistory/.

42. Gelband H, Duse AG. GARP: Executive summary. S Afr Med J. 2011;101(8):552-5.

43. ECDC. European challenges on antimicrobial resistance from a one health perspective [Internet]. 2012 [cited 2017 Jun 26]. Available from: http://ecdc. europa.eu/en/aboutus/who-we-are/Director\%20Speeches/20120314_AMR_ presentation_Copenhagen_EUpresidency.pdf.

44. WHO. Global NCD Action Plan [Internet]. 2014 [cited 2017 Jun 25]. Available from: http://www.who.int/nmh/publications/ncd-infographic-2014.pdf.

45. WHO. Noncommunicable diseases: the slow motion disaster [Internet]. who.int. 2017 [cited 2017 Jun 25]. Available from: http://www.who.int/publications/10year-review/ncd/en/.

46. UNAIDS. South Africa | UNAIDS [Internet]. unaids.org. 2015 [cited 2017 Jun 25]. Available from: http://www.unaids.org/en/regionscountries/countries/ southafrica.

47. WHO. Noncommunicable Diseases (NCD) Country Profiles - South Africa [Internet]. 2014 [cited 2017 Jun 25]. Available from: http://www.who.int/nmh/ countries/zaf_en.pdf.

48. Trading Economics. South Africa Unemployment Rate 2000-2017 [Internet]. tradingeconomics.com. 2017 [cited 2017 Jun 25]. Available from: tradingeconomics.com/south-africa/unemployment-rate.

49. UNAIDS. India | UNAIDS [Internet]. unaids.org. 2015 [cited 2017 Jun 25]. Available from: http://www.unaids.org/en/regionscountries/countries/india/.

50. WHO. Noncommunicable Diseases Country Profiles 2014 [Internet]. 2014 [cited 2017 Jun 25]. Available from: http://apps.who.int/iris/ bitstream/10665/128038/1/9789241507509_eng.pdf.

51. WHO. Density of Nursing and Midwifery Personnel [Internet]. gamapserver. who.int. 2017 [cited 2017 Jun 25]. Available from: http://gamapserver.who.int/ gho/interactive_charts/health_workforce/NursingMidwiferyDensity/tablet/atlas. html.
52. WHO. Density of Pharmaceutical Personnel [Internet]. gamapserver.who. int. 2017 [cited 2017 Jun 25]. Available from: http://gamapserver.who.int/gho/ interactive_charts/health_workforce/PharmaceuticalDensity/tablet/atlas.html.

53. WHO. Density of Physicians [Internet]. gamapserver.who.int. 2017 [cited 2017 Jun 25]. Available from: http://gamapserver.who.int/gho/interactive_charts/ health_workforce/PhysiciansDensity_Total/tablet/atlas.html.

54. WHO. The Abuja Declaration: Ten Years On [Internet]. who.int. 2011 [cited 2017 Jun 25]. Available from: http://www.who.int/healthsystems/publications/ abuja_declaration/en/.

55. Trading Economics. South Africa - Health expenditure, total (\% of GDP) [Internet]. tradingeconomics.com. 2017 [cited 2017 Jun 25]. Available from: https://tradingeconomics.com/south-africa/health-expenditure-total-percent-ofgdp-wb-data.html.

56. The World Bank. Health expenditure, total (\% of GDP) [Internet]. data. worldbank.org. 2017 [cited 2017 Jun 25]. Available from: http://data.worldbank. org/indicator/SH.XPD.TOTL.ZS.

57. South African Department of Health. National Health Insurance in South Africa - Policy Paper [Internet]. 2011 [cited 2017 Jun 25]. Available from: http://www. gov.za/sites/www.gov.za/files/nationalhealthinsurance.pdf.

58. United Nations. Sustainable Development Goals [Internet]. un.org. 2017 [cited 2017 Jun 25]. Available from: http://www.un.org/sustainabledevelopment/ sustainable-development-goals/.

59. Harbarth S, Samore MH. Antimicrobial Resistance Determinants and Future Control. Emerg Infect Dis. 2005;11(6):794-801.

60. Whiteside A. How HIV / AIDS impacts on the health sector. AIDS Anal Afr. 1997;7(2):8-11.

61. Bayer R, Edington C. HIV Testing, Human Rights, and Global AIDS Policy: Exceptionalism and Its Discontents. J Health Polit Policy Law. 2009;34(3):30123.

62. WHO. Noncommunicable diseases [Internet]. who.int. 2017 [cited 2017 Jun 25]. Available from: http://www.who.int/mediacentre/factsheets/fs355/en/.

63. Smith K, Dorfman L, Freudenberg N, Hawkins B, Hilton S, Razum O, et al. Tobacco, Alcohol, and Processed Food Industries - Why Do Public Health Practitioners View Them So Differently? Front Public Health [Internet]. 2016;11;4. Available from: http://www.ncbi.nlm.nih.gov/pmc/articles/ PMC4826885/.

64. WHO. Unhealthy commodity producers, conflict of interest and effective health governance [Internet]. [cited 2017 Jun 25]. Available from: http://www.who.int/ global-coordination-mechanism/dialogues/Private-sector-role-Conflicts-Interst. pdf?ua=1.

65. Durrant C. The responsibility of the pharmaceutical industry. Clin Microbiol Infect. 2001 Dec 1;7:2-4.

66. Aiello AE, King NB, Foxman B. Ethical Conflicts in Public Health Research and Practice. Am J Public Health. 2006;96(11):1910-4.

67. Access to Medicine Foundation. Merck \& Co., Inc. [Internet]. accesstomedicineindex.org. 2016 [cited 2017 Jun 25]. Available from: https:// accesstomedicineindex.org/report-cards/merck-co-inc/.

68. Access to Medicine Foundation. GlaxoSmithKline plc [Internet]. accesstomedicineindex.org. 2016 [cited 2017 Jun 25]. Available from: https:// accesstomedicineindex.org/report-cards/glaxosmithkline-plc/.

69. Access to Medicine Foundation. Johnson \& Johnson [Internet]. accesstomedicineindex.org. 2016 [cited 2017 Jun 25]. Available from: https:// accesstomedicineindex.org/report-cards/johnson-johnson/.

70. Access to Medicine Foundation. Novartis AG [Internet]. accesstomedicineindex. org. 2016 [cited 2017 Jun 25]. Available from: https://accesstomedicineindex. org/report-cards/novartis-ag/.

71. Access to Medicine Foundation. Merck KGaA [Internet]. accesstomedicineindex. org. 2016 [cited 2017 Jun 25]. Available from: https://accesstomedicineindex. org/report-cards/merck-kgaa/.

72. Access to Medicine Foundation. Access to Medicine Index [Internet]. accesstomedicineindex.org. 2016 [cited 2017 Jun 26]. Available from: http:// accesstomedicineindex.org/.

73. Access to Medicine Foundation. Best and innovative practices [Internet]. accesstomedicineindex.org. 2016 [cited 2017 Jun 26]. Available from: http:// accesstomedicineindex.org/best-innovative-practices/.

74. Access to Medicine Foundation. Report cards [Internet]. accesstomedicineindex. org. 2016 [cited 2017 Jun 26]. Available from: http://accesstomedicineindex. org/report-cards/.

75. Access to Medicine Foundation. Collaborative research models appear effective in engaging the industry in developing urgently needed products with 
low commercial potential [Internet]. accesstomedicineindex.org. 2016 [cited 2017 Jun 26]. Available from: http://accesstomedicineindex.org/key-findings/ collaborative-research-models-appear-effective-in-engaging-the-industry-indeveloping-urgently-needed-products-with-low-commercial-potential/.

76. Access to Medicine Foundation. Good practice in making products affordable and available is limited [Internet]. accesstomedicineindex.org. 2016 [cited 2017 Jun 26]. Available from: http://accesstomedicineindex.org/key-findings/goodpractice-making-products-affordable-available-limited/.

77. WHO. Towards Access 2030 - WHO Medicines and Health Products Programme Strategic Framework 2016 - 2030 [Internet]. 2017 [cited 2017 Jun 26]. Available from: http://www.who.int/medicines/publications/Towards_ Access_2030_for_web.pdf?ua=1.

78. United Nations. Millennium Development Goals [Internet]. un.org. 2017 [cited 2017 Jun 25]. Available from: http://www.un.org/millenniumgoals/.

79. United Nations. Sustainable Development Knowledge Platform - Transforming our world: the 2030 Agenda for Sustainable Development [Internet]. sustainabledevelopment.un.org. 2017 [cited 2017 Jun 25]. Available from: https://sustainabledevelopment.un.org/post2015/transformingourworld.

80. United Nations. Sustainable Development Knowledge Platform - Sustainable Development Goal 10 [Internet]. sustainabledevelopment.un.org. 2017 [cited 2017 Jun 25]. Available from: https://sustainabledevelopment.un.org/sdg10.

81. United Nations. Sustainable Development Knowledge Platform - Sustainable Development Goal 4 [Internet]. sustainabledevelopment.un.org. 2017 [cited 2017 Jun 25]. Available from: https://sustainabledevelopment.un.org/sdg4.

82. Adams RJ. Improving health outcomes with better patient understanding and education. Risk Manag Healthc Policy. 2010;3:61-72.

83. WHO. Superbugs: The world is taking action, but low-income countries must not be left behind [Internet]. who.int. 2017 [cited 2017 Jun 25]. Available from: http://www.who.int/mediacentre/commentaries/2017/superbugs-taking-action/ en/.

84. WHO. Antimicrobial resistance - country progress in the implementation of the global action plan on antimicrobial resistance: WHO, FAO and OIE global tripartite database [Internet]. who.int. 2017 [cited 2017 Jun 25]. Available from: http://www.who.int/antimicrobial-resistance/global-action-plan/database/en/.

85. WHO. WHO updates Essential Medicines List with new advice on use of antibiotics, and adds medicines for hepatitis C, HIV, tuberculosis and cancer [Internet]. 2017 [cited 2017 Jun 25]. Available from: http://www.who.int/ mediacentre/news/releases/2017/essential-medicines-list/en/.

86. WHO. WHO Model List of Essential Medicines - 20th List [Internet]. 2017 [cited 2017 Jun 25]. Available from: http://www.who.int/medicines/publications/ essentialmedicines/20th_EML2017.pdf?ua=1.
87. WHO. World Antibiotic Awareness Week [Internet]. 2017 [cited 2017 Jun 25]. Available from: http://www.who.int/campaigns/world-antibiotic-awarenessweek/2017/event/en/.

88. WHO. Global priority list of antibiotic-resistant bacteria to guide research, discovery, and development of new antibiotics [Internet]. who.int. 2017 [cited 2017 Jun 25]. Available from: http://www.who.int/medicines/publications/globalpriority-list-antibiotic-resistant-bacteria/en/.

89. WHO. Report of the First Meeting of the Interagency Coordination Group on Antimicrobial Resistance [Internet]. 2017 [cited 2017 Jun 25]. Available from: http://www.who.int/antimicrobial-resistance/interagency-coordination-group/ IACG-firstMtgReport.pdf?ua=1.

90. WHO. SAVE LIVES: Clean Your Hands 5 May 2017 [Internet]. who.int. 2017 [cited 2017 Jun 25]. Available from: http://www.who.int/infection-prevention/ campaigns/clean-hands/2017/en/.

91. UAEM. Universities Allied for Essential Medicines [Internet]. uaem.org. [cited 2017 Jun 26]. Available from: https://uaem.org/.

92. Maciag K, Kishore SP. A step in the right direction. Nat Rev Microbiol. 2010;8(4):244-244.

93. Kishore SP, Tavera G, Hotez PJ. The Global Health Crisis and Our Nation's Research Universities. PLoS Negl Trop Dis. 2010;4(2):e635.

94. Chokshi DA. Improving Access to Medicines in Poor Countries: The Role of Universities. PLOS Med. 2006;3(6):e136.

95. Greenberg A, Kiddell-Monroe R. Re Routing Biomedical Innovation: observations from a mapping of the alternative research and development (R\&D) landscape. Glob Health. 2016;12(1):54.

96. UAEM. Cases of UK government using compulsory licenses [Internet]. UAEM Evidence. 2014 [cited 2017 Jun 26]. Available from: https://uaemevidence. wordpress.com/2014/11/03/cases-of-uk-government-using-compulsorylicenses/.

97. UAEM. Drug price increases are common in the USA [Internet]. UAEM Evidence. 2016 [cited 2017 Jun 26]. Available from: https://uaemevidence. wordpress.com/2016/05/16/drug-price-increases-are-common-in-the-usa/.

98. UAEM. Evergreening is common [Internet]. UAEM Evidence. 2016 [cited 2017 Jun 26]. Available from: https://uaemevidence.wordpress.com/2016/05/16/ evergreening-is-common/.

99. UAEM. MSF 3P (Push, Pull, Pool) Project for TB [Internet]. UAEM Evidence. 2014 [cited 2017 Jun 26]. Available from: https://uaemevidence.wordpress. com/2014/10/14/msf-3p-push-pull-pool-project-for-tb/.

100. MacNeil CA. Bridging generations: Applying 'adult' leadership theories to youth leadership development. New Dir Youth Dev. 2006;1(109):27-43.

101. Checkoway BN, Gutierrez LM. Youth Participation and Community Change: An Introduction: Journal of Community Practice: J Community Pract. 2006;14(1-2):1-9. 